\title{
HBV Seroconversion After Using Rituximab
}

\author{
Rituksimab Tedavisi Alanlarda HBV Serokonversiyonu
}

\author{
İlyas Öztürk', Mehmet Gündoğdu², Yusuf Bilen ${ }^{3}$, Hakan Sapmaz ${ }^{4}$ \\ ${ }^{1}$ Erzurum Regional Training and Research Hospital, Internal Medicine Department, Erzurum; ${ }^{2}$ Erzincan Binali Yildirm University \\ Faculty of Medicine, Hematology Department, Erzincan; ${ }^{3}$ Adryaman University Faculty of Medicine, Hematology Department, \\ Adiyaman; ${ }^{4}$ Selim State Hospital, Internal Medicine, Kars
}

\begin{abstract}
Aim: It is known that there is an increase in reactivation of Hepatitis $B$ virus (HBV) in immunosuppressive conditions especially after using Rituximab. In this study we aimed to evaluate the HBV seroconversion in patients who have been treated with different regimens containing Rituximab. We examined the relationship between the diagnosis of the patients, the given treatments to patients and $H B V$ reactivation.
\end{abstract}

Material and Method: In this study, 157 patients having Rituximab treatment were evaluated retrospectively in the aspect of HBV seroconversion, in Ataturk University Medicine Faculty Hematology Clinic, between 1 January 2010-31 December 2014.

Results: Of the patients, 96 (61.1\%) were male and 61 (38.9\%) were female. The mean age was 59.75 (21-91) years. When alanine aminotransferase (ALT), Hepatitis $B$ virus surface antigen ( $H B s A g)$ and Hepatitis $B$ virus-deoxyribonucleic acid (HBV-DNA) levels before treatment and at least one year follow up period after treatment were evaluated; 13 (8.2\%) patients had HBV infection reactivation, 84 (53.5\%) patients had no HBV infection reactivation, and also 60 (38.3\%) patients weren't evaluated after treatment. In the analysis of the treatments that patients took, patients diagnosis and HBV infection reactivation at least one year follow up period after the treatment, there wasn't seen statistical difference.

Conclusion: As a result of this study, it was concluded that it would be appropriate to raise the awareness of physicians about the follow-up of HBV infection in patients who are planned or receiving Rituximab treatment and to provide standardization in the follow-up of these patients.

Key words: rituximab; $\mathrm{HBV}$; seroconversion

\section{ÖZET}

Amaç: Immünsupresyon durumlarında ve özellikle Rituksimab kullanımı sonrasında HBV reaktivasyonunda artıș olduğu bilinmektedir. Bu çalıșmada Rituksimab içeren farklı rejimlerle tedavi edilen hastalarda HBV serokonversiyonunu değerlendirmeyi amaçladık. Hastaların tanıları ve almıș olduğu tedaviler ile HBV serokonversiyonu arasındaki ilișkiyi inceledik.
Materyal ve Metot: Çalıșmamızda, Atatürk Üniversitesi Tıp Fakültesi Hematoloji Kliniğinde, 1 Ocak 2010-31 Aralık 2014 tarihleri arasında Rituksimab tedavisi alan 157 hasta geriye dönük olarak HBV seroversiyonu yönünden değerlendirildi.

Bulgular: Hastaların 96'sı (\%61.1) erkek, 61'i (\%38.9) kadındı. Hastaların ortalama yașı 59.75 (21-91) idi. Hastaların tedavi öncesi $A L T, H B s A g$ ve HBV-DNA düzeyleri ile almıș olduğu tedaviler ve tedavi sonrası en az 1 yıllık izlem süresi sonrası ALT, HBsAg ve HBV-DNA düzeyleri değerlendirildiğinde; tedavi sonrası 13 hastada (\%8.2) HBV enfeksiyonu reaktivasyonu olduğu, 84 hastada (\%53.5) HBV enfeksiyonu reaktivasyonu olmadığı, 60 hastanın (\%38.3) ise değerlendirilmemiș olduğu tespit edildi. Hastaların almıș olduğu tedaviler, tanıları ve tedavi sonrası en az 1 yıllık izlem süresi sonrasında görülen HBV enfeksiyonu reaktivasyonu durumu incelendiğinde istatistiksel fark gözlenmedi.

Sonuç: Çalıșmamız neticesinde Rituksimab tedavisi planlanan veya almakta olan hastaların HBV enfeksiyonu açısından daha yakın takip edilmesi gerektiği kanaatine varıldı. Ayrıca bu hususta doktorlara farkındalık kazandırılması ve takip açısından standardizasyon sağlanması gerektiği kanaatine varıldı.

Anahtar kelimeler: rituksimab; HBV; serokonversiyon

\section{Introduction}

Immunosuppression increases the reactivation risk of chronic or treated Hepatitis B virus (HBV) infection ${ }^{1}$. It is declined that in the HBV carriers, who took chemotherapy without having prophylactic treatment, the rate of reactivation is $20-50 \%{ }^{2}$. Suppression in the immune system leads to hepatitis reactivation by allowing an increase in viral replication as the result of increased Hepatitis B virus-deoxyribonucleic acid (HBV-DNA) polymerase activity. With the increase of HBV-DNA 
and Hepatitis B virus envelope antigen ( $\mathrm{HBeAg})$, the decrease in Hepatitis B virus surface antibody (anti$\mathrm{HBs}$ ) and reappearance in Hepatitis B virus surface antigen ( $\mathrm{HBsAg}$ ) occurs ${ }^{1}$. HBV reactivation isn't limited only to the patients with $\mathrm{HBsAg}(+)$, also it can be seen in patients with $\mathrm{HBsAg}(-)$ Hepatitis $\mathrm{B}$ virus core antibody $(\mathrm{HBcAb})(+)^{3}$. Interruption in cytotoxic treatment will stop the immunosuppression and bring back the immune response in $\mathrm{HBV}$-infected hepatocytes. Rituximab has been associated with HBV reactivation when it is combined Anthracycline and steroids with/ or monotherapy ${ }^{1,4}$.

International health organizations recommend screening for $\mathrm{HBV}$ infection prior to treatment regimens that suppress the immune system ${ }^{1,5}$. In 2013 September, U.S. Food and Drug Administration (FDA) warned that there was an $\mathrm{HBV}$ reactivation risk at the patients using monoclonal antibodies against B-cell surface antigen CD20 (anti-CD20) Rituximab and Ofatumumab ${ }^{1,3}$. This warning suggests that screening in the aspect of HBV infection before the Rituximab (R) treatment, screening HBV infected patients in the aspect of HBV infection clinical signs and reactivation, stopping the Rituximab and combined regimens when $\mathrm{HBV}$ infection reactivation occurs, organising the treatment if there is an $\mathrm{HBV}$ infection reactivation while receiving Rituximab ${ }^{1,5}$.

In this study it was aimed to evaluate the HBV seroconversion at the patients who were treated with different regimens containing Rituximab in Hematology Clinic of Ataturk University with various hematological diagnosis between the years 2010-2014, at least end of the one year follow up period after treatment.

\section{Materials and Methods}

In our study, patients having $\mathrm{R}$ treatment were evaluated retrospectively in the aspect of $\mathrm{HBV}$ seroconversion in Ataturk University Medicine Faculty Hematology Clinic between the dates 1 January 2010-31 December 2014. Patients' genders, ages, diagnosis, the main treatment protocols, the number of $\mathrm{R}$ treatments, the level of alanine aminotransferase (ALT)/aspartate aminotransferase (AST)/HBsAg/ anti-HBS/HBcAb/HBV-DNA before treatment and at least one year of follow up period after treatment, relationship between the diagnosis and HBV seroconversion, relationship between the main treatment and HBV seroconversion was studied. Patients who didn't complete the at least one year follow up period after the treatment, who were treated without Rituximab due to $\mathrm{HBsAg}(+)$ before the treatment and who had another malignancy that could affect the result negatively were left out of the study. HBVDNA assay was studied by Magnetic-Bind method. Data were collected retrospectively from the hospital automation system and patient files. A written informed consent was obtained from the patients.

Data analysis was performed using the package program Statistical Package for the Social Sciences 18.0 (SPSS). Data were presented by numbers and percentages. For the statistical analysis, Pearson Chi Square test was used. The level of significance was taken as $\mathrm{p}<0.05$.

Ethics committee approval was received from the Ethics Committee of Atatürk University Faculty of Medicine with the decision number 27 of the session no 1 .

\section{Results}

Our study was done single-centered and retrospectively. 157 patients were reached at the end of the study. $96(61.1 \%)$ of these patients were male and 61 (38.9\%) were female. The mean age of the patients was 59.75 (21-91).

The distribution of cases' diagnosis and their main treatments are shown in Table 1 and Table 2.

When the number of treatments that the patients took were evaluated; 77 patients $(49.0 \%)$ received $1-4$ cycles, 55 patients $(35.1 \%)$ received $5-8$ cycles, 20 patients $(12.7 \%)$ received $9-12$ cycles, 5 patients $(3.2 \%)$ received 13 or more cycles of $\mathrm{R}$ treatment.

When the results of $\mathrm{HBs} \mathrm{Ag}$ examinations were evaluated before the treatment; 88 (56.1\%) were negative, $8(5.1 \%)$ positive, $61(38.8 \%)$ were not evaluated by ELISA. Among the $88 \mathrm{HBsAg}(-)$ patients; 35 (22.3\%) of them weren't evaluated with $\mathrm{HBcAb}, 31$ (19.8\%) of them were $\mathrm{HBs} \mathrm{Ag}(-) \mathrm{HBcAb}(-), 22$ (14\%) of them were $\mathrm{HBs} \mathrm{Ag}(-) \mathrm{HBcAb}(+)$. Among the 61 patients who weren't evaluated HBsAg with ELISA before the treatment; $57(36.3 \%)$ of them were HAS test (-), 3 $(1.9 \%)$ of them weren't evaluated with HAS test, 1 $(0.6 \%)$ of them was HAS test $(+)$.

When anti-HBs levels of the patients before the treatment were evaluated; 54 (34.4\%) of them were anti$\mathrm{HBs}(-), 40$ (25.5\%) of them were anti-HBs(+), 63 $(40.1 \%)$ of them weren't evaluated with anti-HBs. 
Table 1. Dist ribution of diagnoses

\begin{tabular}{ccc}
\hline Diagnoses & Number & Ratio (\%) \\
\hline NHL & 88 & 56.1 \\
\hline CLL & 35 & 22.3 \\
\hline HCL & 8 & 5.1 \\
\hline ITP & 8 & 5.1 \\
\hline MCL & 6 & 3.8 \\
\hline BL & 5 & 3.2 \\
\hline SMZL & 3 & 1.9 \\
\hline WM & 2 & 1.3 \\
\hline AA & 1 & 0.6 \\
\hline OIHA & 1 & 0.6 \\
\hline Total & 157 & 100.0 \\
\hline $\begin{array}{l}\text { NHL:Non-Hodgkin Lymphoma, CLL:Chronic Lym phocytic Leukemia, HCL:Hairy Cell Leukemia, ITP:Immune Trombosytopenic } \\
\text { Makrog lobulinemia, AA:Aplastic Anemia, OlHA:Otoimmune Haemolytic Anemia }\end{array}$
\end{tabular}

Table 2. Distribution of main tre atments

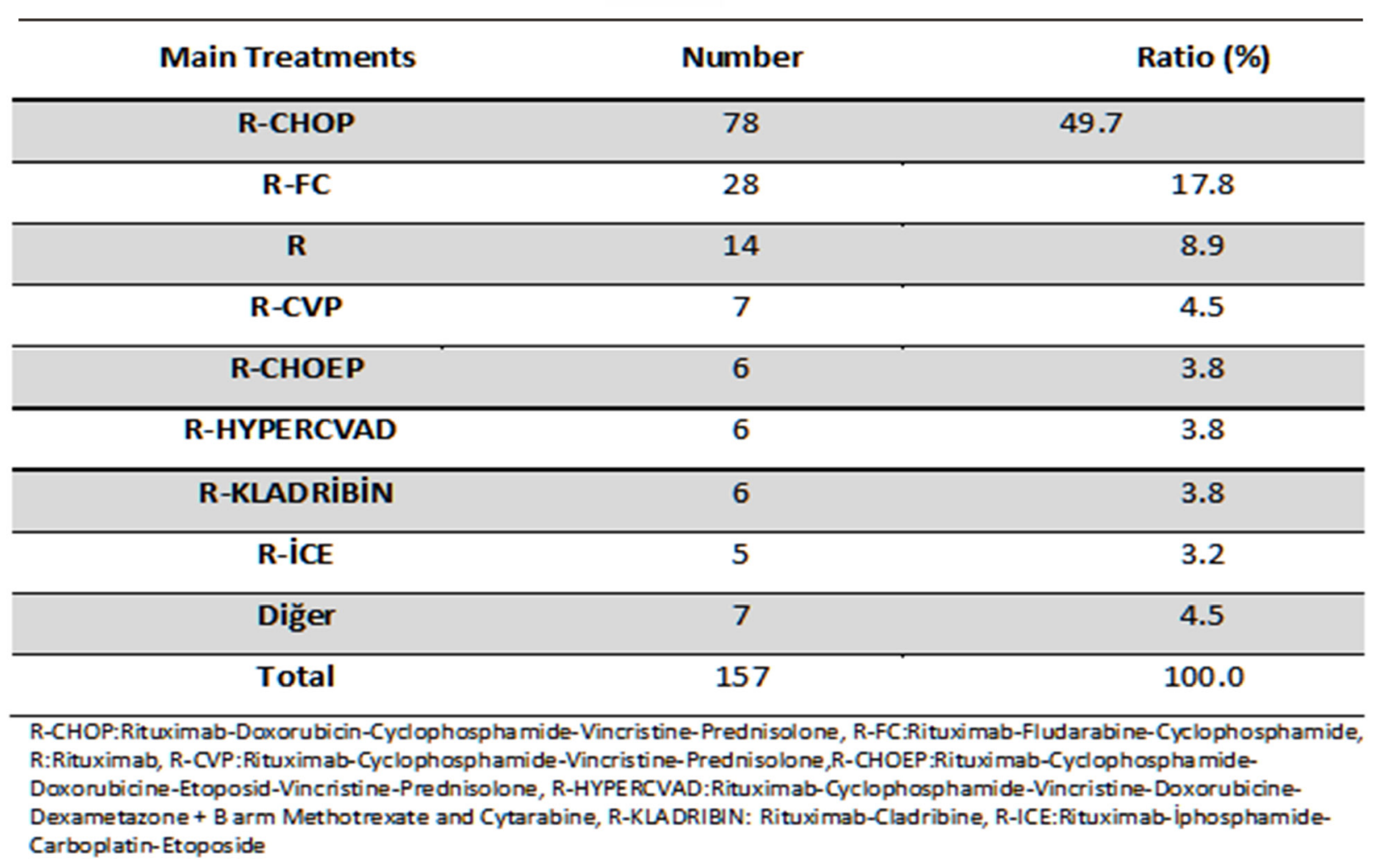


When the HBV-DNA level of patients before the treatment were evaluated; $22(14.0 \%)$ of them were HBV-DNA(-), 2 (1.3\%) of them were HBVDNA(+), $133(84.7 \%)$ of them weren't evaluated with HBV-DNA. HBV-DNA levels of the patients with HBV-DNA (+) were measured as $38 \mathrm{IU} / \mathrm{ml}$ and $39940 \mathrm{IU} / \mathrm{ml}$.

When the HBsAg examinations performed after at least one year follow-up period were compared with the pre-treatment examinations; Of the 31 patients with $\mathrm{HBsAg}(-) \mathrm{HBcAb}(-)$ prior to treatment, 12 (7.7\%) of them were HBsAg (-), 1 (0.6\%) of HBsAg $(-) \mathrm{HBcAb}(+)$ and 18 (11.5\%) of them were not evaluated. Of the 22 patients with pre-treatment $\mathrm{HBsAg}(-) \mathrm{HBcAb}(+), 5$ (3.2\%) HBsAg (-) HBcAb $(-), 4(2.5 \%)$ HBsAg (-) HBcAb (+) and 1 (0.6\%) Isolated HBV-DNA (+) at $3235 \mathrm{IU} / \mathrm{ml}$ level and 12 (7.7\%) were not evaluated. Among the $35 \mathrm{HBsAg}(-)$ $\mathrm{HBcAb}$ weren't evaluated patients before the treatment, 7 (4.5\%) of them were $\operatorname{HBsAg}(-), 2$ (1.3\%) of them were $\mathrm{HBsAg}(-) \mathrm{HBcAb}(+), 1(0.6 \%)$ of them was HBsAg(+) but HBV-DNA(-), 1 (0.6\%) of them was HAS(+) but weren't evaluated furthermore, 24 (15.3\%) of them weren't evaluated after the treatment. Among the $8 \mathrm{HBsAg}(+)$ patients before the treatment, 6 (3.8\%) of them were $\operatorname{HBs} A g(+), 2$ (1.3\%) of them weren't evaluated after the treatment. Among the 2 patients with $\mathrm{HBV}-\mathrm{DNA}(+)$ at first, 1 of them was HBV-DNA(-) and another one had a reduction in viral load after the treatment. Of the 57 patients with HAS (-) who had not evaluated with HBsAg before treatment, 19 (12.1\%) HBsAg (-), 5 (3.2\%) HBsAg (-) $\mathrm{HBcAb}(+), 1(0.6 \%) \mathrm{HAS}(+)$ but was not evaluated furthermore and 32 (20.4\%) were not evaluated, after the treatment. Among the $3 \mathrm{HBsAg}$ and HAS weren't evaluated patients before the treatment, $1(0.6 \%)$ of them was HBsAg(-), 2 (1.3\%) of them weren't evaluated after the treatment. 1 of HBsAg weren't evaluated $\mathrm{HAS}(+)$ patient before the treatment wasn't evaluated after the treatment.

Clinically, HBV infection reactivation is defined as ALT $>3^{*}$ Upper Limit of Normal (ULN) or as elevation on the baseline HBV-DNA level or as HBsAg seroconversion $^{6,7}$. When ALT, HBsAg and HBVDNA levels before treatment and at least one year of follow up period after treatment were evaluated comparatively; 13 (8.2\%) patients had HBV infection reactivation, $84(53.5 \%)$ of them had no infection and also $60(38.3 \%)$ of them weren't evaluated after treatment. Among these patients with reactivation; 9 (5.7\%) of them had Rituximab-CyclophosphamideDoxorubicine-Vincristine-Prednisolone (R-CHOP) treatment, 3 (1.9\%) of them had RituximabFludarabine-Cyclophosphamide (R-FC) treatment, 1 $(0.6 \%)$ of them had $\mathrm{R}$ treatment. Among these patients with reactivation; $9(5.7 \%)$ of them had Non-Hodgkin Lymphoma (NHL), 3 (1.9\%) of them had Chronic Lymphocytic Leukemia (CLL), 1 (0.6\%) of them had Splenic Marginal Zone Lymphoma (SMZL) diagnosis. The clinical features of these patients, the results of the pre- and post-treatment investigations are detailed in Table 3.

As a result of our study, 13 patients with HBV infection reactivation were observed; Anti-viral treatment was started before Rituximab treatment to 2 HBsAg(+) patients with high HBV-DNA levels and it was detected that HBV-DNA levels decreased significantly in these patients after at least 1 year followup period. These 2 patients' baseline HBV-DNA levels were $39.940 \mathrm{IU} / \mathrm{mL}$ and $38 \mathrm{IU} / \mathrm{mL}$ respectively and their HBV-DNA levels decreased to $164 \mathrm{IU} / \mathrm{mL}$ and 0 $\mathrm{IU} / \mathrm{mL}$ under antiviral treatment. In the follow-up of 1 patient who received 6 cycles of R-FC treatment with CLL diagnosed with initial $\mathrm{HBsAg}(-) \mathrm{HBcAb}(+)$ anti-HBs (-); HBV-DNA level was increased to 3235 IU / mL. 4 patients who were $\operatorname{HBs} A g(+)$ before the treatment had $\mathrm{R}$ treatment under the antiviral treatment and at least one year follow up period after the treatment it was seen that countable HBV-DNA level wasn't determined as $\mathrm{HBs} \mathrm{Ag}(+)$ was going on. In one patient who received 5 cycles of R-FC treatment with CLL with initial HBsAg (-), HBsAg (+) was detected after at least 1 year of follow-up, but no measurable HBV-DNA was detected. At other 5 patients, serious ALT-AST increase $(>3 *$ ULN) was determined during treatment and/or after it, but the clinical or laboratory findings of HBV infection weren't seen.

Although it was thought that these patients may have developed hepatitis due to tumor infiltration, hepatotoxic exposure due to other drugs, additional disease, severe sepsis-Disseminated Intravascular Coagulopathy (DIC), because of the follow-up of HBV infection was not fully performed (exitus, patient non-follow-up, the relevant examinations were not made regularly) HBV infection reactivation could not be ruled out.

In the analysis we found that there was no statistical relationship (Pearson Chi Square value:11.43, p:0.782). between the treatments that patients took and HBV 
Table 3. Clinical features, pre and post-treatment examination results of the patients with HBV seroconversion

\begin{tabular}{|c|c|c|c|c|c|c|c|c|c|c|c|c|c|c|c|}
\hline \multirow[b]{2}{*}{ 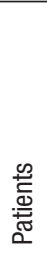 } & \multirow[b]{2}{*}{ 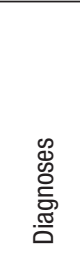 } & \multirow[b]{2}{*}{ 党 } & \multirow[b]{2}{*}{ 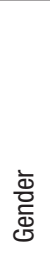 } & \multirow[b]{2}{*}{ 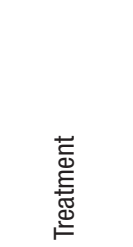 } & \multirow[b]{2}{*}{ 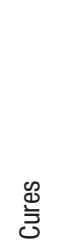 } & \multirow[b]{2}{*}{ 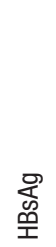 } & \multirow[b]{2}{*}{$\begin{array}{l}\text { 웡 } \\
\text { ㄸ }\end{array}$} & \multicolumn{4}{|c|}{ Baseline } & \multicolumn{4}{|c|}{ Result } \\
\hline & & & & & & & & 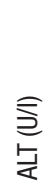 & 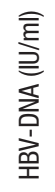 & $\begin{array}{l}\text { 몷 } \\
\text { @̣ }\end{array}$ & $\begin{array}{l}\text { 웛 } \\
\text { 모 }\end{array}$ & $\begin{array}{l}\underset{\mathrm{E}}{\mathrm{E}} \\
\text { 要 }\end{array}$ & 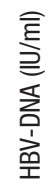 & 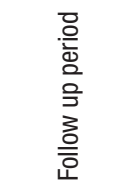 & 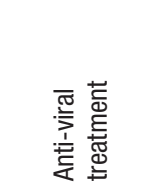 \\
\hline 1 & NHL & 55 & $M$ & $\mathrm{R}-\mathrm{CHOP}$ & 8 & $(-)$ & $(+)$ & 30 & NO & $(-)$ & $(+)$ & 119 & NO & 18 MONTH & NO \\
\hline 2 & $\mathrm{NHL}$ & 81 & $M$ & $\begin{array}{c}\text { R-CHOP + } \\
\text { R-VinB }\end{array}$ & 9 & $(-)$ & NO & 23 & NO & $(-)$ & NO & 1721 & NO & 13 MONTH & NO \\
\hline 3 & NHL & 66 & $M$ & $\begin{array}{c}\text { R-CHOP + } \\
\text { R-ICE }\end{array}$ & 7 & NO & NO & 43 & NO & $(-)$ & $(-)$ & 287 & NO & 13 MONTH & NO \\
\hline 4 & CLL & 72 & $M$ & $\mathrm{R}-\mathrm{FC}$ & 6 & $(-)$ & $(+)$ & 11 & $(-)$ & $(-)$ & NO & 17 & $(+)$ & 16 MONTH & ENTECAVIR \\
\hline 5 & $\mathrm{NHL}$ & 61 & $M$ & $\begin{array}{c}\text { R-CHOP + } \\
\text { R-DHAP }\end{array}$ & 9 & $(+)$ & $(+)$ & 18 & $(-)$ & $(+)$ & $(+)$ & 8 & NO & 12 MONTH & ENTECAVIR \\
\hline 6 & $\mathrm{NHL}$ & 34 & $M$ & $\mathrm{R}-\mathrm{CHOP}$ & 1 & $(+)$ & NO & 24 & $(-)$ & $(+)$ & NO & 42 & $(-)$ & 33 MONTH & $\begin{array}{c}\text { LAMIVUDINE+ } \\
\text { TENOFOVIR }\end{array}$ \\
\hline 7 & NHL & 49 & $M$ & $\mathrm{R}-\mathrm{CHOP}$ & 4 & $(+)$ & $(+)$ & 28 & $(-)$ & $(+)$ & $(+)$ & 28 & $(-)$ & $41 \mathrm{MONTH}$ & LAMIVUDINE \\
\hline 8 & NHL & 54 & $M$ & $\mathrm{R}-\mathrm{CHOP}$ & 6 & $(+)$ & NO & 13 & $(+)$ & $(+)$ & NO & 27 & $(-)$ & 14 MONTH & LAMIVUDINE \\
\hline 9 & CLL & 64 & $M$ & $\mathrm{R}-\mathrm{FC}$ & 5 & $(-)$ & NO & 11 & $(-)$ & $(+)$ & NO & 10 & $(-)$ & $21 \mathrm{MONTH}$ & TENOFOVIR \\
\hline 10 & CLL & 58 & $M$ & $\begin{array}{l}\text { R-FC + } \\
\text { R-DHAP }\end{array}$ & 9 & $(+)$ & $(-)$ & 18 & $(+)$ & $(+)$ & $(-)$ & 38 & $(+)$ & 14 MONTH & LAMIVUDINE \\
\hline 11 & SMZL & 49 & $M$ & R & 16 & $(+)$ & NO & 19 & $(-)$ & $(+)$ & $(+)$ & 17 & $(-)$ & 26 MONTH & LAMIVUDINE \\
\hline 12 & $\mathrm{NHL}$ & 48 & $M$ & $\mathrm{R}-\mathrm{CHOP}$ & 6 & NO & NO & 23 & NO & NO & NO & 261 & NO & 13 MONTH & NO \\
\hline 13 & $\mathrm{NHL}$ & 73 & $M$ & $\mathrm{R}-\mathrm{CHOP}$ & 6 & $(-)$ & NO & 15 & NO & NO & NO & 246 & NO & 27 MONTH & NO \\
\hline
\end{tabular}

HBsAg:Hepatitis B surface antigen, HBcAb:Hepatitis B core antibody, ALT:Alanine aminotransferase, HBV-DNA:Hepatitis B virus-deoxyribonucleic acid, NHL:Non-Hodgkin Lymphoma, CLL:Chronic Lymphocytic Leukemia, SMZL:Splenic Marginal Zone Lymphoma, M:Male, R-CHOP:Rituximab-Doxorubicin-Cyclophosphamide-Vincristine-Prednisolone R-VINB:Rituximab-Vinblastin, R-ICE:Rituximab-Ifosfamide-

Carboplatin-Etoposide, R-FC:Rituximab-Fludarabine-Cyclophosphamide, R-DHAP:Rituximab-Dexamethazone-high dose Cytarabine-Cisplatin, R:Rituximab

infection reactivation at least one year of follow up period after the treatment.

\section{Discussion}

It is known that there is a risk of reactivation of $\mathrm{HBV}$ infection in patients taking Rituximab, an anti-CD20 monoclonal antibody. Therefore; screening for HBV infection is recommended before $\mathrm{R}$ treatment.

$\mathrm{HBV}$ infection reactivation can be observed up to 1 year after the use of rituximab $b^{3,4,9}$.

Despite the fact that the screening was suggested for the patients using Rituximab in the aspect of $\mathrm{HBV}$ infection by FDA in 2013 and United States Center for Disease Control and Prevention (CDC) guidelines in 2008, it was determined that this implementation was at low levels in clinical practice.

In the study made by A.N.Leonard et al. ${ }^{1}$ the screening rates were compared before and after the CDC guidelines suggestion in 2008. The screening rates in the aspect of $\mathrm{HBV}$ infection reactivation before $\mathrm{R}$ treatment was $22 \%$ between 2006-2008, and this rate was 32\% between 2009-2012 years. In the study on 2512 cancer patients made by Ping-I Hsu et al. ${ }^{10}$ $\mathrm{HBV}$ infection screening rate increased to $99.3 \%$ from $40.2 \%$ by an electronic reminding system. In the study made by Ramirez et al. ${ }^{5}$ among the 404 Lymphoma patients who took chemotherapy between the years 1993-2008 only 15 of them (3.7\%) were screened in the aspect of $\mathrm{HBV}$ infection. In the same study, after they developed a pre-treatment screening protocol for the patients who would take R treatment in 2011, the rate increased to $68.7 \%$ (among 48 patients, 33 of them) between the years 2011 and 2012 .

In our study, the screening rate was $61.2 \%$ in the aspect of $\mathrm{HBV}$ infection before the $\mathrm{R}$ treatment.

In the study made by Chih-An Shih et al. ${ }^{2}$ the HBV infection reactivation risk was defined as $25 \%$ higher at 
hematological malignancies than the other solid organ malignancies after the immunosuppressive treatments at the $\mathrm{HBs} \mathrm{Ag}(+)$ patients. Reactivation rate was higher in the patients having $\mathrm{R}$ treatments. For this reason, it was thought that screening before the treatment in the aspect of $\mathrm{HBV}$ infection and giving prophylaxis if necessary is more important for these patients. Although the patients with severe hepatitis exacerbations had antiviral treatment, the mortality rate was $28 \%$.

In the study made by Perrillo et al. ${ }^{11} \mathrm{HBV}$ infection reactivation rate was $40 \%$ after chemotherapy at the $\mathrm{HBsAg}(+)$ patients. Among these patients 13\% had liver failure and $16 \%$ had death.

In the study on $128 \mathrm{HBV}$ infection carriers having different solid organ malignancies made by Yeo W et al. ${ }^{12}$ $\mathrm{HBV}$ infection reactivation rate was $28.1 \%(36 / 128)$ after cytotoxic chemotherapy. The proportional excess of breast cancer and NHL patients was found to be remarkable in the HBV infection reactivation group.

In our study it was detected that antiviral treatment was given before $\mathrm{R}$ treatment to 2 patients with $\mathrm{HBsAg}(+)$ and high HBV-DNA levels, and HBV-DNA levels had significant decrease after at least one year follow up period.

Four patients with $\mathrm{HBsAg}(+) \mathrm{HBcAb}(+) \mathrm{HBV}-$ DNA(-) before treatment took $\mathrm{R}$ treatment under antiviral treatment were found to have continued HBsAg(+) and no countable HBV-DNA levels after at least one year follow up period. One patient who had HBsAg(-) before treatment, had HBV-DNA(+) after at least one year follow up period.

In the studies made by Chih-An Shih et al. ${ }^{2}$ and Yeo $\mathrm{W}$ et al. ${ }^{12}$, patients with solid organ malignancies were evaluated. But, when our study is compared with these studies, it has restrictive data due to having only hematological diseases. Also the studies made by Chih-An Shih et al. ${ }^{2}$ and Yeo W et al. ${ }^{12}$ were made in endemic areas in the aspect of HBV infection, so it was arrived at the opinion that the reactivation rates could be higher than our studies.

In the study made by Liang-Tsai Hsiao et al. ${ }^{7}$ the anti$\mathrm{HBs}(+)$ rate in patients having $\mathrm{R}$ treatment was determined as $78 \%$.

In our study we found that anti-HBs(-) rate was $34.4 \%$, (+) rate $25.5 \%$, untested anti-HBs rate was $40.1 \%$ before the treatment. Turkish Liver Research Association made TURK-HEP study in our country between the years 2008-2011 and by these results it was seen that $\mathrm{HBsAg}(+)$ rate was $4 \%, \mathrm{HBcAb}(+)$ rate was $30.6 \%$, anti-HBs $(+)$ rate was $32 \%{ }^{12}$. So, the data that we had in our study was in parallel situation with our country's data.

In the study made by Fabrizio Marcucci et al. ${ }^{13} 399$ NHL diagnosed patients' and 392 control group patients' blood serum were examined in the aspect of HBV infection's laboratory findings. The $\mathrm{HBsAg}(+)$ prevalence was found as $8.5 \%$ (34/399) in NHL diagnosed patients and in control group this rate was found as $2.8 \%(11 / 392)$.

In the study made by Feng Wang et al. ${ }^{14} 586$ patients with NHL and 1237 patients with solid organ malignancies were examined in the aspect of $\mathrm{HBV}$ infection. The HBsAg $(+)$ prevalence was found 27\% (160/586) in NHL diagnosed patients and in control group this rate was found as $15 \%(183 / 1237)$. This rate was found $30 \%(128 / 424)$ at B-cell NHL diagnosed patients and $20 \%(32 / 162)$ at T-cell NHL diagnosed patients.

In this study, it was thought that HBV virus that is known as lymphotropic, has more effect on the B-lymphocytes.

In the retrospective study on 276 Hodgkin Lenfoma (HL) and NHL diagnosed patients made by Abdullah Altıntaş et al. ${ }^{8}$ the $\mathrm{HBsAg}(+)$ prevalence was $14.5 \%$ (40/276). But, this rate was $16.4 \%$ at HL diagnosed patients and $13.7 \%$ at NHL diagnosed patients. HBsAg(+) prevalence rate was $90 \%$ in male patients and $10 \%$ in female patients. The Anti-HBs(+) prevalence was $44.5 \%$, but this rate was $39.7 \%$ in HL diagnosed patients and $46.3 \%$ in NHL diagnosed patients.

In the TURK-HEP study made by Turkish Liver Research Association in our country between the years 2008-2011, $\mathrm{HBsAg}(+)$ rate was $4 \%, \mathrm{HBcAb}(+)$ rate was $30.6 \%$, anti-HBs $(+)$ rate was $32 \%{ }^{15,16}$.

In our study, pre-treatment $\mathrm{HBs} \mathrm{Ag}(+)$ prevalence was $5.1 \%(8 / 157)$. The HBsAg $(+)$ prevalence was found as $0.8-5.7 \%$ by the different studies in our country ${ }^{15,17}$. So, $\mathrm{HBs} \mathrm{Ag}(+)$ rate in our study is similar to our country's data.

In the study made by Liang-Tsai Hsiao et al. ${ }^{7}$ Rituximab related $\mathrm{HBV}$ seroconversion was as the highest rate with $40 \%$ at the post-transplant lymphoproliferative disorders (PTLD) patients after allogeneic stem cell transplantation. Similarly, it was found that the HBV seroconversion increased at the Allogeneic stem cell 
transplant (HSCT) patients. Presence of immunosuppression before Rituximab treatment is thought to cause increased risk in these patients.

In our study there isn't any statistical difference between the diagnoses of patients and HBV seroconversion (Pearson Chi Square value:19.98, p:0.334). Stem cell transplantation procedure was not performed in any of the patients included in our study between 2010 and 2014 and there is no data on this subject.

In the study made by Liang-Tsai Hsiao et al. ${ }^{7}$ Rituximab related HBV seroconversion was more frequently at the patients who take the treatments more than 6 times. The number and intensity of ritu ximab treatment in these patients was thought to be related to the decline in anti-HBs levels by the destruction on B-lymphocytes.

In the study made by Kai-Lin Chen et al. ${ }^{4} \mathrm{HBV}$ infection reactivation developed after 5-6 times chemotherapy and 1 to 13 months later after the treatment.

In our study, among the 13 patients who had HBV seroconversion at the end of the follow up period, 10 of them (76.9\%) took 6 and more R treatment, and also 3 of them (23.1\%) took the R treatment less than 6 .

In the study made by Kai-Lin Chen et al. ${ }^{4}$ the HBV infection reactivation after $\mathrm{R}$ treatment was much more in $\mathrm{HBsAg}(-) \mathrm{HBcAb}(+)$ patients with the $10.9 \%$ rate than the $\mathrm{HBsAg}(-) \mathrm{HBcAb}(-)$ patients. Among the $165 \mathrm{HBsAg}(-)$ patients, of whom $33.3 \%$ were $\mathrm{HBsAg}(-) \mathrm{HBcAb}(+)$, the $\mathrm{HBV}$ infection reactivation incidence was 3.6\% (6/165). Baseline $\mathrm{HBcAb}(+)$ presence, high level of ALT and AST was thought to be an independent risk factor in the aspect of $\mathrm{HBV}$ infection reactivation.

In the study made by Kosei Matseu et al. ${ }^{18}$ at the 252 $\mathrm{HBsAg}(-)$ patients, of whom $24.3 \%$ was $\mathrm{HBsAg}(-)$ $\mathrm{HBcAb}(+)$, the $\mathrm{HBV}$ infection reactivation incidence after the $\mathrm{R}$ treatment was as $2 \%(5 / 252)$. Also, all these 5 patients were $\mathrm{HBsAg}(-) \mathrm{HBcAb}(+)$. The $\mathrm{HBV}$ infection reactivation incidence of the $\mathrm{HBsAg}(-) \mathrm{HBcAb}(+)$ patient group was $8.9 \%$ $(5 / 56)$. Among these 5 patients, 4 of them were anti$\mathrm{HBs}(-)$ before the treatment. There was an increase in the reactivation risk at the $\mathrm{HBsAg}(-) \mathrm{HBcAb}(+)$ anti-HBs(-) patients.

In the study made by Chiun Hsu et al. ${ }^{19}$ among the $150 \mathrm{HBsAg}(-) \mathrm{HBcAb}(+)$ NHL diagnosed patients, 27 (18\%) of them had the HBV infection reactivation after the R-CHOP treatment. Among these 27 patients, 16 (59\%) of them were anti-HBs(+) before the treatment. In this study it was thought that the anti$\mathrm{HBs}(+)$ was related to the increase of $\mathrm{HBV}$ infection reactivation risk.

In the study on $80 \mathrm{HBsAg}(-) \mathrm{CD} 20(+)$ Diffuse Large B-cell Lymphoma (DLBCL) diagnosed patients made by Winnie Yeo et al. ${ }^{20}$ among the $46(57.5 \%) \mathrm{HBcAb}(+)$ patients, 21 (26.2\%) of them had R-CHOP treatment and $25(31.3 \%)$ of them had CHOP treatment. Among the patients who had R-CHOP treatment, 5 (6.2\%) of them had $\mathrm{HBV}$ infection reactivation. However, at the patients who had CHOP treatment had not HBV infection reactivation. At the $34(42.5 \%) \mathrm{HBcAb}(-)$ patients who had R-CHOP or CHOP treatment, none of them had HBV infection reactivation. Also, in this study it was thought that the absence of anti-HBs and being male gender was a risk factor for $\mathrm{HBV}$ infection reactivation.

In our study, among the 157 patients, 13 (8.2\%) of them had HBV infection reactivation. Among the 22 patients who were $\mathrm{HBs} \mathrm{Ag}(-) \mathrm{HBcAb}(+)$ before treatment, $1(4.5 \%)$ of them had HBV infection reactivation and this patient was anti-HBs(-) before treatment.

At the end of our study, it was found that all of the 13 patients at whom the reactivation was seen, were male and the average age of this group was 58.7. Also in the study made by Winnie Yeo et al. ${ }^{12}$ male gender was reported as a risk factor for $\mathrm{HBV}$ infection.

As recommended in many guidelines and studies, it was concluded that the prophylactic antiviral treatment would be beneficial for the $\mathrm{HBsAg}(+)$ or $\mathrm{HBsAg}(-) \mathrm{HBcAb}(+)$ patients who will use high-risk medication for hepatitis exacerbation or who have high-risk disease for hepatitis exacerbation throughout the treatment process and till at least one year after treatment.

However; since our search was single-centered and retrospective study, it contains limited information in terms of results. So, in this situation it should be supported with multi-centered and prospective studies.

As a result of this study, it was concluded that it would be appropriate to raise the awareness of physicians about the follow-up of $\mathrm{HBV}$ infection in patients who are planned or receiving Rituximab treatment and to provide standardization in the follow-up of these patients. 


\section{References}

1. Leonard A. N, Love B. L, Norris L. B, Siddiqui S. K, Wallam M. $\mathrm{N}$, Bennett C. L. Screening for viral hepatitis prior to rituximab chemotherapy. Ann Hematol 2016;95:27-33.

2. Shih C-A, Chen W-C, Yu H-C, Cheng J-S, Lai K-H, Hsu J-T et al. Risk of severe acute exacerbation of chronic HBV infection cancer patients who underwent chemotherapy and did not receive anti-viral prophylaxis. PloS One 2015;10:1-11.

3. Seto WK. Hepatitis B virus reactivation during immunosuppressive therapy: Appropriate risk stratification. WJH 2015;7:825-30.

4. Chen K-L, Chen J, Rao H-L, Ying G, Huang H-Q, Zhang L et al. Hepatitis $\mathrm{B}$ virus reactivation and hepatitis in diffuse large B-cell lymphoma patients with resolved hepatitis B receiving rituximab-containing chemotherapy: risk factors and survival. Chin J Cancer 2015;34:18-30.

5. Ramirez J, Duddempudi A. T, Sana M. M, Hasan S. S, Santos M, Song J et al. Screening for hepatitis B in patients with lymphoma. Proc Bayl Univ Med Cent 2015;28:438-43.

6. Cagın YF, Seckin Y. Immunosuppressive Treatment-Induced Hepatitis B Virus Reactivation. GG 2016;20:130-6.

7. Hsiao L-T, Chiou T-J, Gau J-P, Yang C-F, Yu Y-B, Liu C-Y et al. Risk of Reverse Seroconversion of Hepatitis B Virus Surface Antigen in Rituximab-Treated Non-Hodgkin Lymphoma Patients: A Large Cohort Retrospective Study. Med 2015;94:112.

8. Altıntas A, Kaplan M. A, Cil T, Yılmaz S, Bayan K, Danıs R et al. Hepatitis B Infection and Clinical Significance in Hodgkin and Non-Hodgkin Lymphoma Cases. UHOD 2007;17:1-6.

9. Pattullo V. Hepatitis B reactivation in the setting of chemotherapy and immunosuppression-prevention is better than cure. WJH 2015;7:954-67.

10. Hsu P-I, Lai K-H, Cheng J-S, Kao S-S, Li Y-R, Sun W-C et al. Prevention of acute exacerbation of chronic hepatitis B infection in cancer patients receiving chemotherapy in a hepatitis B virus endemic area. Hepatol 2015;62:387-96.

11. Perrillo RP, Martin P, Lok AS. Preventing hepatitis B reactivation due to immunosuppressive drug treatments. JAMA 2015;313:1617-8.
12. Yeo W, Zee B, Zhong S, Chan P. K. S, Wong W-L, Ho W. $\mathrm{M}$ et al. Comprehensive analysis of risk factors associating with Hepatitis B virus (HBV) reactivation in cancer patients undergoing cytotoxic chemotherapy. BJC 2004;90:1306-11.

13. Marcucci F, Mele A, Spada E, Candido A, Bianco E, Pulsoni A et al. High prevalence of hepatitis B virus infection in B-cell non-Hodgkin's lymphoma. Haematologica 2006;91:554-7.

14. Wang F, Xu R, Han B, Shi Y, Luo H, Jiang W et al. High incidence of hepatitis B virus infection in B-cell subtype nonHodgkin lymphoma compared with other cancers. Cancer 2007;109:1360-4.

15. Dursun H, Albayrak A. Current Situation with Current Treatments in Chronic Hepatitis B Treatment and New Targets in the Future. GG 2016;20/2:145-56.

16. Tatematsu K, Tanaka Y, Kurbanov F, Sugauchi F, Mano S, Maeshiro $T$ et al. A genetic variant of hepatitis $B$ virus divergent from known human and ape genotypes isolated from a Japanese patient and provisionally assigned to new genotype J. J Virol 2009;83:10538-47.

17. Akhan S, Aynıglu A, Cagatay A, Gönen I, Gunal O, Kaynar T et al. Management of chronic hepatitis B virus infection: Turkish Clinical Microbiology and Infectious Diseases Association Viral Hepatitis Working Group Consensus Report. Klimik 2014;27:2-18.

18. Matsue K, Kimura S-I, Takanashi Y, Iwama K-I, Fujiwara $H$, Yamakura $M$ et al. Reactivation of hepatitis $B$ virus after rituximab -containing treatment in patients with CD20positive B-cell lymphoma. Cancer 2010;116:4769-76.

19. Hsu C, Tsou H-H, Lin S-J, Wang M-C, Yao M, Hwang M-L et al. Chemotherapy-induced hepatitis $\mathrm{B}$ reactivation in lymphoma patients with resolved HBV infection: A prospective study. Hepatol 2014;59:2092-100.

20. Yeo W, Chan T. C, Leung N. W. Y, Lam W. Y, Mo F. K. F, Chu M. T et al. Hepatitis B virus reactivation in lymphoma patients with prior resolved hepatitis B undergoing anticancer therapy with or without rituximab. J Clin Oncol 2009;27:605-11. 